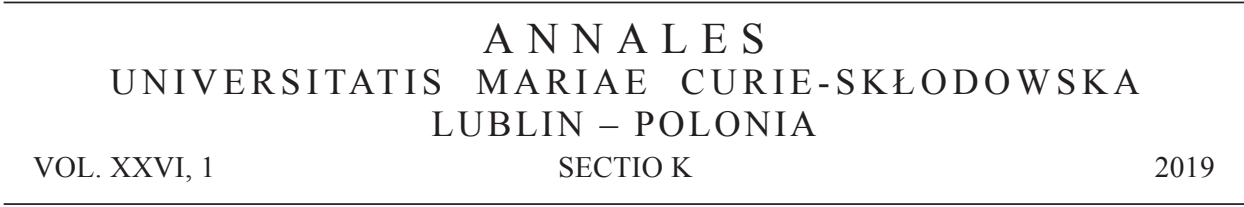

Uniwersytet Śląski w Katowicach

\author{
KATARZYNA BRZOZA
}

ORCID ID: https://orcid.org/0000-0002-5262-5745

\title{
Pierwsza dama w internetowych memach obrazkowych na wybranych przykładach
}

The First Lady in Online Memes on Selected Examples

\begin{abstract}
ABSTRAKT
Badanie dyskursu pojawiającego się w memach jest istotne, ponieważ pokazuje, jakie tematy szczególnie absorbują opinię publiczną. Podstawą dla prowadzonych rozważań będą wyniki analizy ilościowej oraz jakościowej, która została przeprowadzona na ponad 200 memach opublikowanych na portalu Demotywatory.pl. Badania empiryczne oparto na analizie zawartości typu frekwencyjno-tematycznego, a wykorzystanym narzędziem badawczym był program SPSS. Punktem odniesienia teoretycznego uczyniono model zintegrowanego wyjaśniania przyczyn nierówności płci w polityce, który pozwala spojrzeć na materiał badawczy z perspektywy uwzględniającej elementy polityki równościowej. Zrealizowane na potrzeby niniejszego artykułu analizy umożliwiły weryfikację hipotezy badawczej: Przyczyny kulturowe nierówności płci w polityce, w tym zwłaszcza stereotypizacja, to główny element widoczny w obrazie polskiej pierwszej damy, wykreowanym w memach poddanych analizie.

Artykuł podzielono na trzy części. We wprowadzeniu znalazły się podstawowe ustalenia teoretyczne dotyczące aktywności politycznej kobiet oraz memów internetowych. Ponadto szczegółowo przedstawiono metodologię przeprowadzonych badań (metoda badawcza, hipoteza oraz pytania badawcze). Zasadnicza część to prezentacja wyników badań ilościowych i jakościowych wybranych memów internetowych. Celem prowadzonych badań było sprawdzenie tego, jaki obraz pierwszej damy wykreowano w badanych memach. Pokazano różnice i podobieństwa w obrazowaniu pierwszej damy Polski i innych krajów świata. Poszukiwano odpowiedzi na wiele pytań: na co najbardziej zwracają uwagę twórcy memów, jeśli chodzi o obraz żony prezydenta, czy w badanych memach można dostrzec obecność stereotypów płciowych, w jakich okresach zainteresowanie pierwszą damą jest największe i czy na przestrzeni lat coś się w tym zakresie zmieniło? Trzeci fragment to zakończenie, w którym podsumowano rezultaty badań oraz potwierdzono hipotezę badawczą. Obraz pierwszej damy uwidoczniony w analizowanych memach to przykład stereotypowego przedstawiania obrazu kobiety obecnej w sferze polityki, co wpisuje się w przyczyny kulturowe niedoreprezentowania kobiet w polityce, które wskazano w zintegrowanym modelu wyjaśniania przyczyn nierówności płci w polityce.
\end{abstract}

Słowa kluczowe: pierwsza dama, memy, nierówność płci 


\section{WSTĘP}

Bycie żoną polityka to tylko jedna z ról, jedna z możliwych form obecności przedstawicielek płci żeńskiej w świecie polityki. Należy pamiętać, że kobiety czynnie uczestniczą w życiu politycznym przez sprawowanie mandatu lub wykonywanie zawodu dziennikarki, zajmującej się tematyką polityczną. Politolodzy, medioznawcy, socjolodzy, psycholodzy, językoznawcy, kulturoznawcy i reprezentanci wielu innych dyscyplin naukowych wielokrotnie podejmowali rozważania na temat obecności, a raczej (nie)obecności kobiet w świecie polityki, z uwzględnieniem własnej optyki badawczej oraz metodologii badań, właściwej dla danej dyscypliny naukowej. W katalogu badaczy prowadzących analizy na wskazany temat należy wymienić autorów polskich, jak np.: Małgorzata Fuszara, Łukasz Wawrowski, Renata Siemieńska oraz zagranicznych, m.in.: Pippa Norris, Ronald Inglehart, Anne Donatella Campus.

Na rynku wydawniczym można odnaleźć monografie i artykuły naukowe, których autorzy nie tylko badali przyczyny niskiego udziału kobiet w polityce, ale także proponowali wiele klasyfikacji czynników wpływających na niedoreprezentowanie przedstawicielek płci żeńskiej w świecie polityki. Widać tutaj pewną powtarzalność wnioskowania w zakresie determinant poziomu zaangażowania kobiet w życie polityczne. Łukasz Wawrowski w zintegrowanym modelu wyjaśniania przyczyn nierówności płci w polityce wymienił trzy główne elementy:

1) przyczyny instytucjonalne: wpływ cech danego systemu politycznego na odsetek kobiet pełniących funkcje polityczne (pozytywny wpływ systemu proporcjonalnego, dużych okręgów wyborczych i niewielkiej liczby partycypujących w podziale mandatów ugrupowań, a także stosowane kwoty w procesie selekcji kandydatów);

2) przyczyny strukturalne (społeczne): kształt systemu społecznego, i tutaj podkreśla się znaczenie edukacyjnej, ekonomicznej i zawodowej pozycji kobiet;

3) przyczyny kulturowe: wpływ sposobu postrzegania ról społecznych, stopień przyzwolenia na aktywność kobiet w sferze publicznej i treści przekazywane w trakcie procesów socjalizacji [Wawrowski 2009: 147-148].

Przywołany model posłuży jako punkt odniesienia do analizy wizerunku pierwszej damy w memach. Uwzględnienie takiej perspektywy otwiera szansę na sprawdzenie, które z wyliczonych przyczyn niedoreprezentowania kobiet w polityce mają największą siłę oddziaływania, co przejawia się w określonej kreacji obrazu pierwszej damy w badanych memach. Wymienione w modelu przyczyny instytucjonalne wpływają bardzo mocno na osobę kandydata, a tylko pośrednio na jego małżonkę, ale trzeba pamiętać słowa „starego powiedzenia [...] o mężczyźnie świadczy kobieta, z którą się związał [...] Pierwszą damę wskazujemy niejako dodatkowo, głosujemy przecież na męża, ale jakkolwiek by było, wybieramy reprezentacyjny tandem, więc wizerunek żony zawsze będzie towarzyszył wizerunkowi prezydenta czy kandydata na prezydenta" [Kowalska 2010]. Na wizerunek żony prezydenta, ale także jej rolę w polityce mogą również oddziaływać przyczyny kulturowe i społeczne, pojawiające 
się w modelu zarówno w okresie kampanii wyborczej, jak i w czasie sprawowania funkcji pierwszej damy. „Małżonka kandydata na prezydenta ma być jego tłem lub jego alter ego - uzupełnieniem wizerunku przyszłego prezydenta. W trakcie kampanii jest niejako w otoczeniu męża, a jej zadaniem jest ukazywanie bliskiej więzi i swojej podległości" [Kluczyńska 2010: 74]. Niewątpliwie bycie pierwszą damą, małżonką polityka zwłaszcza na eksponowanym stanowisku nie należy do zadań łatwych, ale kobiety, które znalazły się w takiej rzeczywistości: „Na pytanie czy gdyby przed laty, decydując się na małżeństwo - wiedziały, że ich mąż zaangażuje się w politykę, zmieniłyby zdanie, odpowiadają »nie«. Są zadowolone z życia u boku polityka, choć w większości przyznają, że wiążą się z tym wyrzeczenia. Gdy dzieje się coś ważnego, wszystko musi zejść na drugi plan. A one wtedy muszą być cierpliwe, wytrwałe i mądre, bo tylko przyjmując taką postawę, mogą pozytywnie wpłynąć na wizerunek polityczny swoich mężów" [Prystacka 2006: 46].

Kwestią dyskusyjną pozostaje rola, jaką pełni pierwsza dama, gdyż jest to tytuł honorowy, który nie ma charakteru formalnego. „Ani Konstytucja RP z 1997 r. ani żadna $\mathrm{z}$ obowiązujących $\mathrm{w}$ Polsce ustaw nie nakłada na żonę Prezydenta RP praw i obowiązków wynikających z bycia Pierwszą Damą" [Secler 2009: 155]. Małżonka głowy państwa „nie jest pracownikiem Kancelarii Prezydenta i nie pobiera pensji z tytułu sprawowanej funkcji. W związku z tym jej działalność u boku męża nie jest objęta jakąkolwiek składką emerytalną i nie wlicza się do stażu pracy. Małżonka prezydenta nie ma też gwarancji powrotu do pracy po upływie kadencji” [Prezydent z pensją i przywilejami 2015]. W zasadzie nie ma przepisów uniemożliwiających pierwszej damie zatrudnienie czy pełnienie innych funkcji, a więc teoretycznie takie rozwiązanie jest możliwe, a decyzja należy do żony prezydenta. Jednak w praktyce taka sytuacja byłaby trudna lub nawet niemożliwa ze względu na kwestie bezpieczeństwa, protokół dyplomatyczny i konieczność unikania niejasności, a także zachowania „czystości urzędu” [Krężlak-Dzieciątek 2015]. Tematem wynagrodzenia dla pierwszej damy chciał się zająć w 2016 roku rząd PiS, ale inicjatywa zakończyła się fiaskiem [Kalisz 2018]. W świetle tych ustaleń przyczyny strukturalne wskazane przez Ł. Wawrowskiego, czyli sfera edukacyjno-zawodowa kobiet, wyodrębniona jako jedna z przesłanek ograniczających udział kobiet w życiu politycznym, może mieć wpływ na obraz pierwszej damy, której sytuacja w tym obszarze nie jest uregulowana prawnie, co z kolei może deprecjonować jej pozycję na polskiej scenie politycznej.

Kobiety stojące u boku męża pełniącego istotne funkcje publiczne przykuwają uwagę, wzbudzają zainteresowanie mediów, opinii publicznej, a podejmowane przez nie działania są szeroko komentowane [Wiśniewska 2014: 455]. Żona prezydenta: „Nie może przesadzić z wydatkami, bo zostanie uznana za zbyt rozrzutną, nie może pójść w drugą stronę, bo zostanie posądzona o brak znajomości protokołu. Słowem, niezależnie od tego, jaką opcję prezentuje jej mąż ona i tak musi chodzić po linie" [Dominiak 2015]. Wszystkie elementy związane z postrzeganiem roli przypisywanej pierwszej damie przez społeczeństwo, ale także stereotypy płciowe przekazywane 
w procesach socjalizacji to składowe przyczyn kulturowych, wymienionych w zintegrowanym modelu wyjaśniania przyczyn nierówności płci w polityce.

Stereotypy nie tylko kształtują oczekiwania jednostki ludzkiej wobec siebie, ale oddziałują na sposób oceniania innych osób dokonywany przez pryzmat ich cech i zachowań związanych z płcią. Wprowadzając rozróżnienie między kobietami a mężczyznami, uwzględniając stereotypowe postrzeganie, bierze się pod uwagę cechy charakteru, zachowania, cechy fizyczne i zajęcia. Te uproszczone wzory powstające w ludzkiej głowie potwierdzają system wartości obowiązujący w danej kulturze, są użyteczne i dają poczucie bezpieczeństwa, ale jednocześnie narzucają pewne ograniczenia, ponieważ kontakt z osobą określonej płci prowadzi do uruchomienia stereotypowych schematów [Brannon 2002: 212-219].

W niniejszym artykule zaprezentowano badania przeprowadzone na memach, czyli „hieroglifach XXI wieku”, współcześnie oznaczających wpół obrazkowy język użytkowników, tzw. nowych mediów [Piskorz 2013: 227-237], który służy nie tylko rozrywce, ale umożliwia także krytykę społeczną oraz jest rodzajem symbolicznego, medialnego protestu [Nowak 2013: 240]. Memy to popularna forma partycypacji internautów, którzy przetwarzają treści, tworzą nowe, dokonują własnej interpretacji i uczestniczą w kulturze. W zasadzie każde wydarzenie, które zainteresuje użytkowników sieci internetowej, może się pojawiać w memach, w których łączy się motywy popkulturowe z tematami akcentowanymi w publicznym dyskursie. Dzięki memom można obserwować społeczne nastroje oraz badać, jakie kwestie najbardziej absorbują opinię publiczną. Sieć internetowa daje wszystkim użytkownikom szansę udziału w debacie publicznej, bez względu na pełnione funkcje czy posiadane kompetencje [Juza 2013: 57-60].

Dane udostępnione przez GUS pokazują, że liczba internautów w Polsce wyniosła $28 \mathrm{mln}$, czyli około 73\% polskiego społeczeństwa stanowią użytkownicy sieci internetowej, dlatego badanie dyskursu toczącego się w przestrzeni wirtualnej jest niezwykle istotne. Skoro ponad połowa Polaków korzysta z internetu, to warto zbadać wirtualny dyskurs, gdyż być może dzięki poznaniu obrazu pierwszej damy proponowanego internautom w memach będzie można odpowiedzieć na wiele pytań i to nie tylko dotyczących obrazowania żony prezydenta w memach, ale także postrzegania miejsca, roli i wizerunku kobiet zaangażowanych w życie polityczne. Trzeba również brać pod uwagę fakt, że młodzi ludzie chętnie przeglądają memy, a to jaki obraz zostanie wykreowany w percepcji obiorców, wpływa na sposób postrzegania konkretnych problemów, tematów czy osób. Badaniu poddano materiały opublikowane w serwisie Demotywatory.pl, ponieważ według badań portalu wirtualnemedia.pl był to najpopularniejszy serwis humorystyczny w latach 2012-2014. Podobne wyniki zaprezentowano na portalu Media2.pl, gdzie również, mimo spadku, serwis Demotywatory.pl utrzymał pozycję lidera w rankingu humorystycznych serwisów internetowych 2014 roku [Wojtas 2015; Szewczyk 2015]. Wykorzystano analizę zawartości, czyli metodę wypracowaną przez środowisko medioznawców, wielokrotnie opisywaną przez polskie autorytety naukowe, m.in.: Walerego Pisarka, Tomasza 
Gobana-Klasa, Stanisława Michalczyka, Małgorzatę Lisowską-Magdziarz. Badania typu frekwencyjno-tematycznego pozwalają określić częstotliwość występowania tematów i aktorów, pewnych trendów w tym względzie, w wybranym odcinku czasu [Michalczyk 2008: 292].

Analiza objęła klasyczne memy obrazkowe, pojawiające się w serwisie Demotywatory.pl po wpisaniu w wewnętrzną wyszukiwarkę hasła „pierwsza dama”. Stan na dzień 4 września 2018 roku to 212 memów. Narzędziem wykorzystanym do badania był program SPSS, w który wprowadzono przygotowany dla celów badawczych klucz kategoryzacyjny, składający się z ośmiu zmiennych.

Głównym celem prowadzonych analiz było uzyskanie odpowiedzi na pytanie, jaki obraz pierwszej damy wykreowano w badanych memach obrazkowych? Ponadto odwołując się do ustaleń zawartych w zintegrowanym modelu wyjaśniania przyczyn nierówności płci w polityce, starano się wskazać, które z wymienionych w modelu przyczyn niedoreprezentowania kobiet w sferze politycznej są widoczne w badanych memach. W toku postępowania badawczego weryfikacji poddano hipotezę: Przyczyny kulturowe nierówności płci w polityce, w tym zwłaszcza stereotypizacja, to główny element widoczny w obrazie polskiej pierwszej damy, wykreowanym w memach poddanych analizie.

Przeprowadzone analizy ilościowe i jakościowe służyły odpowiedzi na siedem szczegółowych pytań badawczych:

1. W jakich okresach zainteresowanie pierwszą damą jest największe?

2. Które pierwsze damy najczęściej pojawiały się w badanych memach?

3. Jaki wydźwięk miały memy przedstawiające pierwsze damy?

4. Na co najbardziej zwracają uwagę twórcy memów, jeśli chodzi o obraz żony prezydenta?

5. Czy w sposobie obrazowania pierwszej damy w memach można dostrzec obecność stereotypów płciowych?

6. Czy w przedstawianiu pierwszej damy Polski i innych krajów świata pojawia się element wspólny, czy raczej mamy do czynienia z różnicami?

7. Czy na przestrzeni lat zmienił się sposób ukazywania pierwszej damy w memach?

\section{WYNIKI ANALIZY ILOŚCIOWEJ I JAKOŚCIOWEJ}

Przeprowadzone analizy wykazały, że najwięcej memów dotyczących pierwszej damy opublikowano w latach 2010 i 2015, kiedy odbywały się w Polsce wybory prezydenckie. Widać zatem, że kampanie prezydenckie wpływają na wzrost zainteresowania żonami kandydatów na prezydenta. Co ciekawe w roku 2010 w memach dotyczących pierwszej damy najczęściej pojawiała się postać Jarosława Kaczyńskiego (96 memów). Internauci prowadzili rozważania na temat stanu cywilnego kandydata na prezydenta, który jak wiadomo jest kawalerem i dlatego stawiali pytanie: „Jeśli 
wygra prezes PiS, to kto będzie pierwszą damą?”. Drugą osobą widoczną w badanych memach w 2010 rok była Anna Komorowska (34 memy). Natomiast rok 2015 to czas największego zainteresowania Agatą Duda (4 memy) oraz ponownie Anną Komorowską (6 memów).

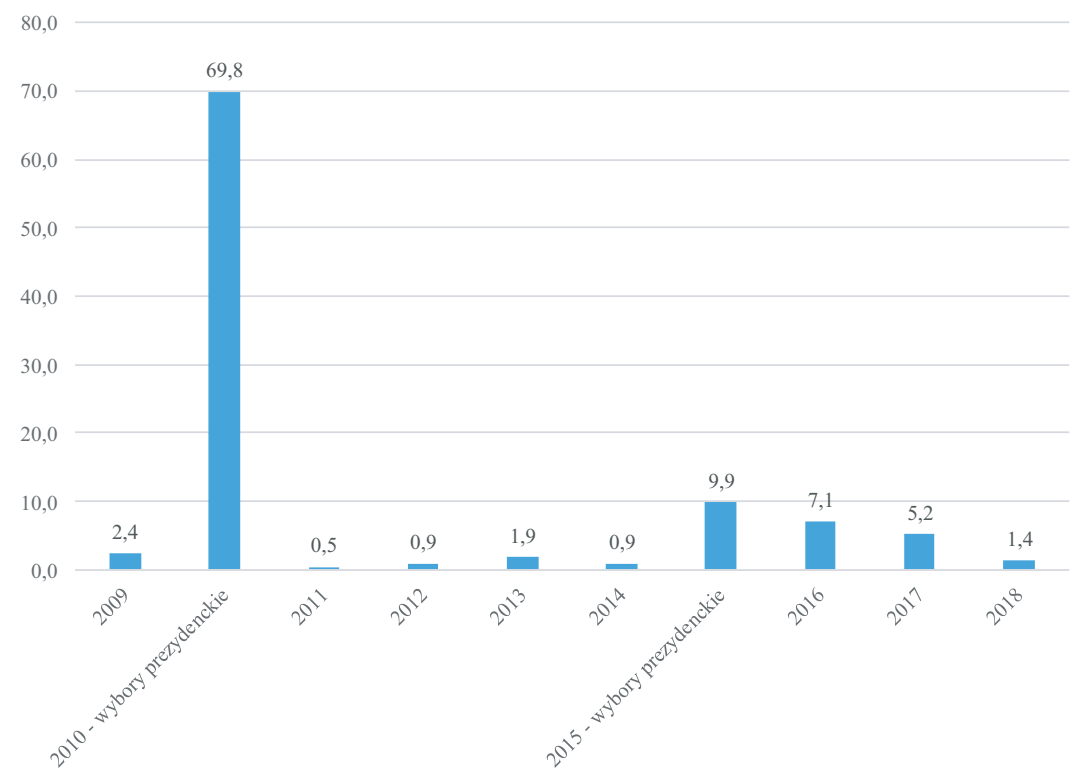

Wykres 1. Rok publikacji mema w serwisie Demotywatory.pl.

Źródło: Wyniki badań własnych. Dane podano w \%.

Prowadzone badania miały umożliwić uzyskanie odpowiedzi na pytanie: które pierwsze damy najczęściej pojawiały się w badanych materiałach? W zasadzie można wskazać kilka głównych elementów tworzących kategorię ,pierwsza dama” w analizowanych memach: a) polska pierwsza dama, b) żony prezydentów innych krajów świata, c) inne kobiety świata polityki (np. Jolanta Szczypińska), d) kobiety niezwiązane z polityką, a określane mianem pierwszej damy (np. Irena Szewińska). Ponadto w interesujących nas memach uwidaczniano mężczyzn, np. Bill Clinton był pokazany jako pierwsza dama, w okresie gdy jego żona Hillary ubiegała się o prezydenturę, lub Justin Biber został przedstawiony jako żona Władimira Putina. Jak już wspomniano, twórcy memów szczególnie dużo uwagi poświęcili Jarosławowi Kaczyńskiemu, który startował w 2010 roku w wyborach prezydenckich (46\%).

Kiedy w badanej próbie pozostawiono tylko te memy, w których faktycznie pojawia się postać pierwszej damy i kobiet związanych ze światem polityki oraz potraktowanych w kategoriach pierwszej damy, wówczas szczegółowej weryfikacji poddawano 101 memów. W tej grupie najwięcej memów dotyczyło polskiej przestrzeni politycznej (74,2\%). Największe zainteresowanie wzbudziła Anna Komorowska (45,5\%), następnie Agata Duda (10,9\%), Maria Kaczyńska (8,9\%), kan- 


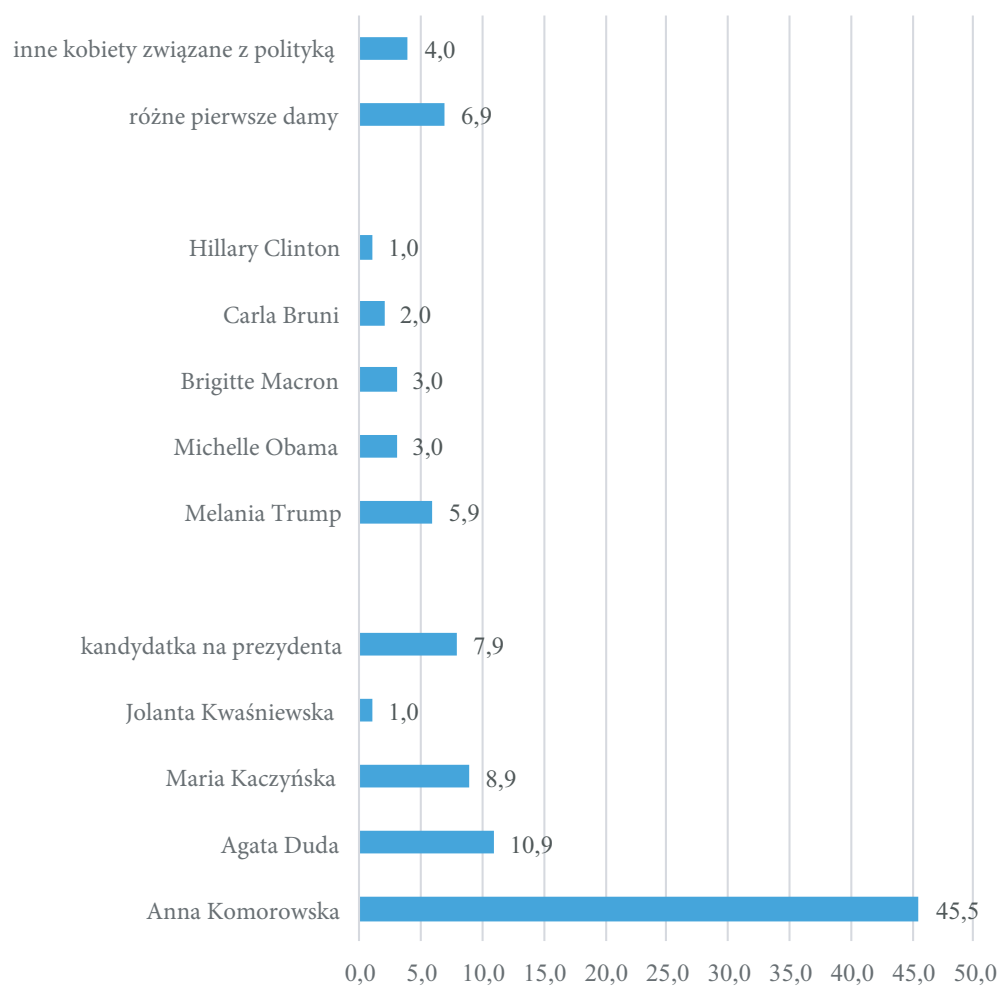

Wykres 2. Pierwsze damy pojawiające się w memach.

Źródło: Wyniki badań własnych. Dane podano w \%.

dydatki na prezydenta (Anna Grodzka i Magdalena Ogórek) (7,9\%) oraz Jolanta Kwaśniewska (1\%). Wśród pierwszych dam świata dominowała Melania Trump (5,9\%), przed Michelle Obama (3\%) i Brigitte Macron (3\%) oraz Carlą Bruni (2\%) i Hillary Clinton (1\%).

Weryfikacji poddano wydźwięki memów z pierwszymi damami. Dominował wydźwięk satyryczny/prześmiewczy, który można było wskazać w 30,7\% memów, natomiast negatywny wydźwięk pojawił się w 26,7\% materiałów, mieszany w $15,8 \%$, neutralny w 10,9\%, pozytywny w 9,9\% i w 5,9\% memów uwidocznił się kontekst seksualny (wyraźnie seksistowski wymiar, np. pierwsza dama ukazana w samej bieliźnie). Tabela 1 pokazuje, jak rozkładały się wydźwięki z uwzględnieniem podziału na poszczególne osoby: a) Anna Komorowska: dominujący wydźwięk to negatywny - 17,8\%; b) Agata Duda: mieszany - 5\%; c) Maria Kaczyńska: negatywny - 3\%; d) Jolanta Kwaśniewska: satyryczny/prześmiewczy - 1\%; f) kandydatki na prezydenta: satyryczny/prześmiewczy - 7,9\%; g) Melania Trump: kontekst seksualny - 3\%; h) Michelle Obama: satyryczny/prześmiewczy - 2\%; i) Brigitte Macron: pozytywny, satyryczny/prześmiewczy i mieszany - równo po $1 \%$; j) Carla Bruni: pozytywny i kontekst seksualny - po 1\%; k) inne pierwsze damy świata polityki: satyryczny/ 
prześmiewczy - 1\%; 1) różne pierwsze damy: neutralny i mieszany - po 3\%; m) inne kobiety związane z polityką: pozytywny, mieszany, satyryczny/prześmiewczy - po 1\%.

Tabela 1. Wydźwięk memów prezentujących pierwsze damy

\begin{tabular}{|l|c|c|c|c|c|c|}
\hline \multirow{2}{*}{$\begin{array}{l}\text { Pierwsza dama widoczna } \\
\text { W memach }\end{array}$} & \multicolumn{7}{|c|}{ Rodzaj wydźwięku w badanych memach } \\
\cline { 2 - 7 } & Neutralny & Pozytywny & Negatywny & Mieszany & $\begin{array}{l}\text { Satyryczny/ } \\
\text { prześmiewczy }\end{array}$ & $\begin{array}{l}\text { Kontekst } \\
\text { seksualny }\end{array}$ \\
\hline Anna Komorowska & 5,0 & 2,0 & 17,8 & 5,0 & 15,8 & - \\
\hline Agata Duda & 1,0 & 2,0 & 3,0 & 5,0 & - & - \\
\hline Maria Kaczyńska & 2,0 & 2,0 & 3,0 & 1,0 & - & 1,0 \\
\hline Jolanta Kwaśniewska & - & - & - & - & 1,0 & - \\
\hline Kandydatka na prezydenta & - & - & - & - & 7,9 & - \\
\hline Melania Trump & - & - & 2,0 & - & 1,0 & 3,0 \\
\hline Michelle Obama & - & 1,0 & - & - & 2,0 & - \\
\hline Brigitte Macron & - & 1,0 & - & 1,0 & 1,0 & - \\
\hline Carla Bruni & - & 1,0 & - & - & - & 1,0 \\
\hline $\begin{array}{l}\text { Inne pierwsze damy świata } \\
\text { polityki }\end{array}$ & - & - & - & - & 1,0 & - \\
\hline Różne pierwsze damy & 3,0 & - & - & 3,0 & - & 1,0 \\
\hline Inne kobiety związane z polityką & - & 1,0 & - & 1,0 & 1,0 & - \\
\hline
\end{tabular}

Źródło: Badanie własne. Dane podano w \%.

Najwięcej uwagi poświęcono wyglądowi pierwszych dam - 59,4\%. Kolejną najczęściej pojawiającą się zmienną związaną z osobą pierwszej damy była pełniona funkcja publiczna $-22,8 \%$, następnie inne $-5 \%$, inteligencja/wykształcenie $-4 \%$, przeszłość $-3 \%$, rodzina $-3 \%$, ubiór $-2 \%$, życie zawodowe $-1 \%$. W przypadku Anny Komorowskiej memom odnoszącym się do jej wyglądu nadawano wydźwięk negatywny (23,3\%). Wygląd kandydatek na prezydenta z 2015 (Anna Grodzka, Magdalena Ogórek) miał w memach głównie wydźwięk satyryczny (11,7\%). Melania Trump to pierwsza dama najczęściej ukazywana w kontekście seksualnym (5\%). Różne pierwsze damy zestawiano ze sobą, porównywano pod względem wyglądu i tutaj dominował wydźwięe neutralny $(5 \%)$.

Drugim elementem wyraźnie widocznym w memach z pierwszą damą było spojrzenie przez pryzmat funkcji publicznej pełnionej przez żonę prezydenta. W tym przypadku dominujący wydźwięki to satyryczny i pozytywny (po 21,7\%). Prześmiewczo patrzono na sposób realizacji zadań pierwszej damy przez Annę Komorowską (21,7\%), a pozytywnie oceniano działania Agaty Duda i Marii Kaczyńskiej (po 8,7\%). W wielu przypadkach sprawowanie roli pierwszej damy oceniano negatywnie $(21,6 \%)$ i tutaj najczęściej ponownie pojawiała się Anna Komorowska (13\%). Podobnie wydźwięki neutralne oraz mieszane (po 17,3\%) zwykle towarzyszyły memom obrazującym działania Anny Komorowskiej. 
Tabela 2. Wizerunek pierwszej damy w badanych memach

\begin{tabular}{|c|c|c|c|c|c|c|c|c|}
\hline \multicolumn{9}{|c|}{ Eksponowane elementy wizerunku pierwszych dam w badanych memach } \\
\hline $\begin{array}{l}\text { Pierwsza dama widoczna } \\
\text { w memach }\end{array}$ & 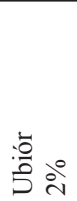 & 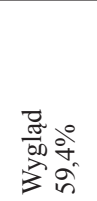 & 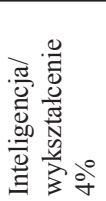 & 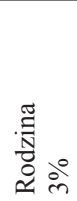 & 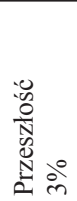 & 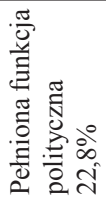 & 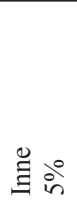 & 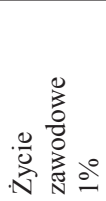 \\
\hline Jolanta Kwaśniewska & - & - & $1 \%$ & - & - & - & - & - \\
\hline Maria Kaczyńska & - & $5 \%$ & - & - & - & $3 \%$ & $1 \%$ & - \\
\hline Anna Komorowska & - & $27,2 \%$ & $2 \%$ & $1 \%$ & $1 \%$ & $12,9 \%$ & $1 \%$ & - \\
\hline Agata Duda & $1 \%$ & $3 \%$ & - & $1 \%$ & - & $4 \%$ & $1 \%$ & $1 \%$ \\
\hline Kandydatka na prezydenta & - & $6,9 \%$ & - & - & - & - & $1 \%$ & - \\
\hline Hillary Clinton & - & - & - & - & - & $1 \%$ & - & - \\
\hline Michelle Obama & - & $1 \%$ & - & - & $1 \%$ & - & $1 \%$ & - \\
\hline Melania Trump & $1 \%$ & $3 \%$ & $1 \%$ & - & $1 \%$ & - & - & - \\
\hline Brigitte Macron & - & $3 \%$ & - & - & - & - & - & - \\
\hline Carla Bruni & - & $2 \%$ & - & - & - & - & - & - \\
\hline $\begin{array}{l}\text { Inne kobiety związane } \\
\text { z polityką }\end{array}$ & - & $1 \%$ & - & $1 \%$ & - & $2 \%$ & - & - \\
\hline Inne pierwsze damy & - & $6,9 \%$ & - & - & - & - & - & - \\
\hline
\end{tabular}

Źródło: Badania własne. Dane podano w \%.

Jedno z pytań badawczych brzmiało: czy w badanych memach można dostrzec obecność stereotypów płciowych w sposobie obrazowania pierwszej damy? Zgromadzone dane pokazują, że stereotypów w memach nie brakowało, co między innymi pokazuje tematyka, w jakiej osadzono postać żony prezydenta.

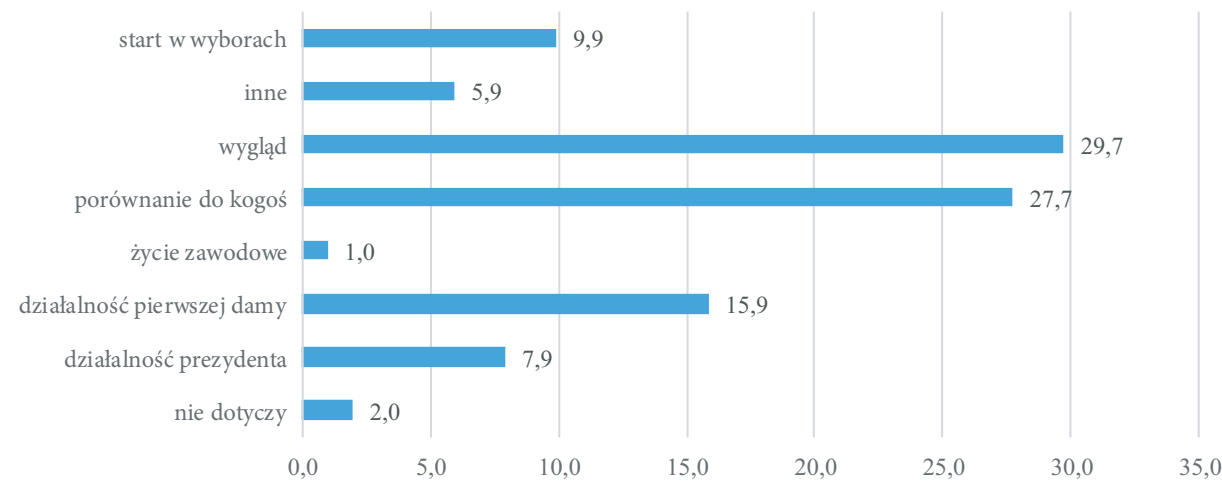

Wykres 3. Temat, w jakim usytuowano pierwszą damę w memach.

Źródło: badania własne. Dane w \%.

Mamy tutaj do czynienia ze stereotypowym postrzeganiem pierwszej damy przez pryzmat wyglądu, który stanowił temat w 29,7\% analizowanych memów. Drugi poruszany w memach kontekst to porównanie do kogoś $(27,7 \%)$ i najczęściej te porównania znowu dotyczyły wyglądu i przypominały „wybory miss”, choć 
pojawiało się także porównanie dotyczące pełnienia funkcji małżonki prezydenta $(15,9 \%)$ i inteligencji (M. Obama i M. Trump). Twórcy memów odnosili się także do działalności pierwszej damy (15,9\%). Postaci pierwszej damy sytuowano w kontekście wyborów prezydenckich (9,9\%), które jak wcześniej stwierdzono, podnosiły zainteresowanie żonami kandydatów. Tutaj kobiety potraktowano niczym żywa wizytówka swojego męża, dlatego w katalogu badanych materiałów chętnie porównywano kandydatki na pierwsze damy. Natomiast w przypadku Magdaleny Ogórek zastanawiano się, czy po wygranych wyborach jej mąż będzie nazywany „pierwszym gentelmanem”, zaś jeśli prezydentem zostanie Anna Grodzka, to będzie „3 w 1 - tak w ramach oszczędności Prezydent, Pierwsza Dama i Pierwszy Mąż” [Demotywatory.pl]. Działalność pierwszej damy traktowano lekceważąco: „Możesz być Pierwszą Damą. Najważniejszą żoną w kraju. Jednak media interesują się tylko tym, w co byłaś ubrana" [Demotywatory.pl]. W badanych memach pojawia się także seksizm płciowy, a kobiety są ukazywane przez pryzmat ciała, np. Melania Trump została przedstawiona w bieliźnie. Najczęściej na grafice pojawiał się cały tułów obrazowanej postaci (56,4\%) lub przedstawiano całą postać pierwszej damy (29,7\%). Ze wszystkich części ludzkiego ciała uwzględnionych w kluczu kategoryzacyjnym widoczna była tylko głowa (5\%).

Pojawiające się w memach porównania zwykle odnosiły się do kobiet, których mężowie startowali w wyborach prezydenckich. Jednak co ciekawe twórcy memów w 2010 roku zestawiali kandydatki na pierwsze damy z kotem Jarosława Kaczyńskiego, który według nich miał być odpowiednikiem żony kandydata na prezydenta $(31,8 \%)$. Internauci często porównywali polskie pierwsze damy z żonami światowych przywódców.
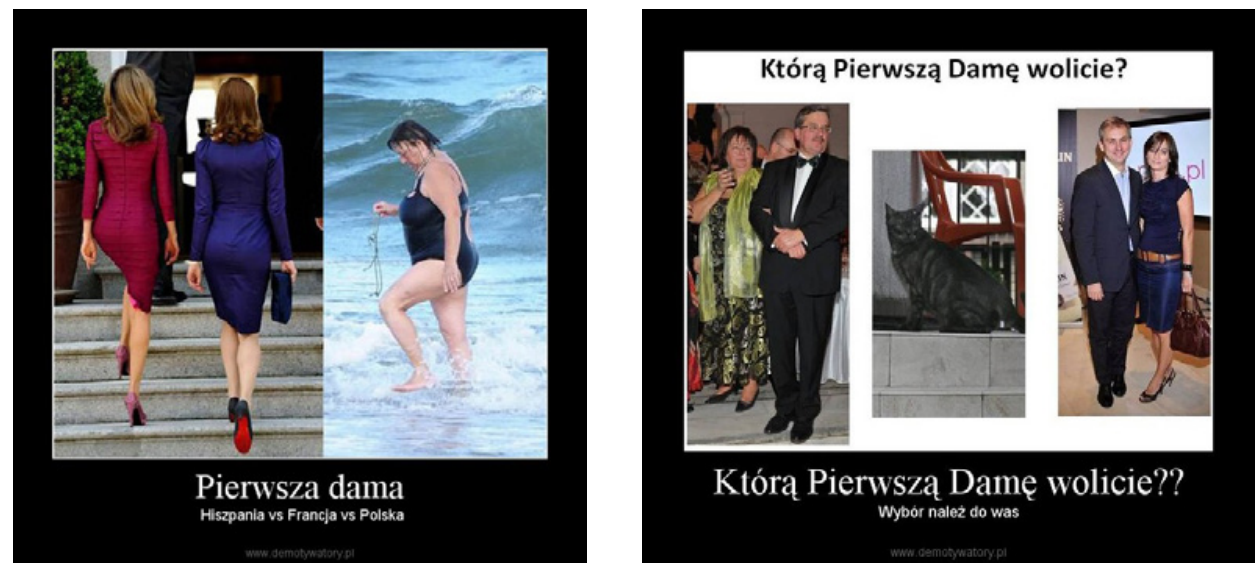

Rycina 1. Przykłady memów, w których pojawia się zestawienie porównawcze pierwszych dam/kandydatek na pierwsze damy. 
Pierwsza dama najczęściej pojawiała się w memach sama $(32,7 \%)$ lub w towarzystwie małżonka $(31,7 \%)$. W memach porównujących żony prezydentów można wskazać kilka pierwszych dam (10,9\%). Najczęściej obrazowana para prezydencka to Anna i Bronisław Komorowscy (21,8\%), Agata i Andrzej Dudowie (4\%), Maria i Lech Kaczyńscy (2\%), Michelle i Barack Obamowie (2\%). Pierwsza dama bez osób trzecich pojawiająca się w memach to najczęściej Anna Komorowska (16,8\%), Maria Kaczyńska (5,9\%) i Melania Trump (3,9\%).

Czy w obrazowaniu pierwszej damy Polski i innych krajów świata pojawiają się elementy wspólne, czy raczej mamy do czynienia z różnicami? Na to pytanie można odpowiedzieć w kilku punktach:

1. Twórcy memów częściej odwołują się do polskiej pierwszej damy $(74,3 \%)$ niż do żon polityków zagranicznych.

2. Zdecydowanie częściej wydźwięk negatywny widać w przypadku polskich pierwszych dam, które są porównywane do ich lepszych zagranicznych „odpowiedników".

3. Pierwsza Dama Ameryki jest „symbolem seksu”, a w przypadku polskich pierwszych dam kontekst seksualny praktycznie się nie pojawia, chyba że w negatywnym odniesieniu.

4. Małżonki polskich prezydentów internauci sytuują w tematach związanych z pełnioną funkcją, natomiast pierwsze damy innych państw świata to piękne wizytówki swoich mężów.

5. To polskie pierwsze damy lub kandydatki na pierwsze damy są porównywane między sobą lub też do pięknych zagranicznych wzorów.

Ostatnie szczegółowe pytanie badawcze oscyluje wokół tego, czy na przestrzeni lat sposób obrazowania pierwszej damy się zmienił. Przeprowadzone analizy pozwoliły dostrzec kilka ważnych elementów:

1. Okres wyborów prezydenckich zwiększa zainteresowanie pierwszą damą. Jednocześnie poza olbrzymim skokiem w 2010 roku, związanym z osobą Jarosława Kaczyńskiego, oraz w 2015 widać, że także w okresach międzywyborczych z roku na rok liczba memów rośnie. Nasuwa się wniosek, że to nie polskie pierwsze damy są coraz śmieszniejsze czy bardziej interesujące dla twórców memów, ale raczej aktywność współczesnego człowieka przenosi się do sieci internetowej, także w obszarze aktywizacji politycznej.

2. Wydźwięki w badanym okresie nie zmieniały się zasadniczo, choć lata 20172018 to czas, kiedy internauci ,sięgają po satyrę”, zaś lata 2009-2010 to dominacja wydźwięku negatywnego w badanych memach. Specyfika roku 2016 polegała na szczególnej ekspozycji kontekstu seksualnego, eksponowanego szczególnie w memach z Melanią Trump, co też ma związek z toczącą się wówczas w USA kampanią prezydencką. Na podstawie uzyskanych wyników można zaryzykować stwierdzenie, że ton wypowiedzi łagodnieje, a wydźwięk negatywny zastępuje satyryczny. 
3. Ekspozycja wyglądu pierwszej damy bez względu na badany rok to najczęściej poruszany wątek w badanych memach.

4. Okres kampanii prezydenckiej to czas, kiedy w memach pojawia się para prezydencka czy kandydat z małżonką, a po wyborach częściej eksponowana jest wyłącznie postać pierwszej damy w kontekście realizowanej funkcji publicznej.

5. W 2010 roku widać porównania do innych osób i ekspozycję wyglądu zewnętrznego pierwszych dam, w 2015 roku akcentowano działalność żony prezydenta, zaś poza okresami wyborczymi nie widać tak wyraźnej dominacji konkretnego wątku.

\section{ZAKOŃCZENIE}

Podsumowując wyniki przeprowadzonych analiz, należy stwierdzić, że obraz pierwszej damy wykreowany w badanych memach miał głównie wydźwięk satyryczny i był przesycony stereotypami płciowymi, a nawet pojawiał się kontekst seksualny. Liczne porównania dotyczyły wyglądu zewnętrznego, a polskie pierwsze damy zestawiano z ich ,lepszymi” zagranicznymi odpowiednikami.

Patrząc na badane memy przez pryzmat zintegrowanego modelu wyjaśniania przyczyn nierówności płci w polityce, można stwierdzić, że przyczyny instytucjonalne nie znalazły odzwierciedlenia w badanym materiale, bo pierwszą damę wybieramy ,przy okazji”, głosując na konkretnego kandydata. Być może brak regulacji dotyczących pozycji i roli pierwszej damy w polskim systemie politycznym wpływa na fakt, że jej znaczenie jest marginalizowane. Można powiedzieć, że zadaniem żony prezydenta jest dbałość o ładny wygląd podczas realizacji funkcji reprezentacyjnych przy boku małżonka. W memach eksponowano elementy wliczone do przyczyn społecznych oraz kulturowych powodujących niedoreprezentowanie kobiet w polityce. Jeżeli chodzi o przyczyny strukturalne (społeczne), twórcy memów odwoływali się do pozycji zawodowej kobiet, kiedy „mówili” o przeszłości pierwszej damy, wykształceniu lub też o zadaniach realizowanych przez żonę prezydenta w okresie kadencji. Natomiast przyczyny kulturowe były widoczne bardzo mocno. Rola pierwszej damy to bycie piękną wizytówką prezydenta. Stereotypy płciowe były łatwe do zaobserwowania w badanym materiale i dotyczyły nie tylko wyglądu zewnętrznego, ale także stanu cywilnego, a nawet wieku.

Joanna Solska na łamach „Polityki” ciekawie podsumowała nie tylko opinie na temat miejsca pierwszej damy w publicznej przestrzeni, ale wysnuła interesujący wniosek na temat przyszłości prezydenckiego małżonka/małżonki, stwierdzając, że: „zawód pierwszej damy był sfeminizowany [...] Teraz jednak coraz częściej »żonami władzy« są mężczyźni, więc proces emancypacji zacznie pewnie postępować szybko. Panowie własnych zarobków ani kariery zawodowej na kieszonkowe zamieniać nie chcą. Zbliża się czas, gdy prezydenci - zarówno mężczyźni, jak i kobiety - będą 
zmuszeni do rezygnacji z paprotki i nauczą się swoje obowiązki wykonywać solo" [Solska 2016]. Czy słowa dziennikarki okażą się prorocze, czas pokaże. Niewątpliwie przywołane stwierdzenie sugeruje, że miejsce kobiet w polityce determinują postawy i działania mężczyzn.

\section{BIBLIOGRAFIA}

Brannon, L. 2002. Psychologia rodzaju. Kobiety i mężczyźni: podobni czy różni, Gdańskie Wydawnictwa Psychologiczne, Gdańsk.

Demotywatory.pl, https://demotywatory.p1/ (dostęp: 4.09.2018).

Dominiak, I. 2015. Czy Polacy płaca za garsonki Pierwszej Damy?, 5.08, http://www.newsweek.pl/polska/agata-duda-co-moze-pierwsza-dama-wydatki-pensja-przywileje, artykuly,368077,1.html (dostęp: 15.09.2018).

Juza, M. 2013. Memy internetowe - tworzenie, rozpowszechnienie, znaczenie społeczne, „Studia Medioznawcze", nr 4, s. 49-60.

Kalisz, P. 2018. Pierwsze Damy będa dostawać państwowa pensję? Z takim postulatem wyszła Anna Komorowska, 3.04, https://natemat.pl/234581,pensja-dla-pierwszej-damy-prezydenci-musza-oplacac-zonom-zus (dostęp: 27.09.2018).

Kluczyńska, U. 2010. Kobiety na „,drugiej linii” władzy? Wizerunki kobiet (bez)pośrednio angażująych się w politykę?, [w:] Kobiety w polityce, J. Marszałek-Kawa (red.), Wydawnictwo Adam Marszałek, Toruń, s. 58-81.

Kowalska, D. 2010. Nie chcemy w Pałacu Prezydenckim matki Polki, http://www.polskatimes.pl/artykul/218020,nie-chcemy-w-palacu-prezydenckim-matki-polki,id,t.html (dostęp: 27.09.2018).

Krężlewicz-Dzieciątek, M. 2015. Ile zarabia pierwsza dama? Nic. Nie otrzymuje wynagrodzenia, nie jest objęta sktadka emerytalna, 25.05, http://m.wiadomosci.gazeta.pl/wiadomosci/1,117915,17982515, Ile_zarabia_pierwsza_dama_Nic_Nie_otrzymuje_wynagrodzenia_html (dostęp: 27.09.2018).

Michalczyk, S. 2008. Spoteczeństwo medialne. Studia z teorii komunikowania masowego, Wydawnictwo Śląsk, Katowice.

Nowak, J., 2013. Memy internetowe: teksty (cyfrowej) kulturyjęzykowej krytyki społecznej, [w:] Wspótczesne media. Język mediów, I. Hoffman, D. Kępa-Figura (red.), Wydawnictwo UMCS, Lublin, s. 227-238.

Piskorz, K. 2013. Internetowe memy - hieroglify XXI wieku, [w:] Wspótczesne media. Język mediów, I. Hoffman, D. Kępa-Figura (red.), Wydawnictwo UMCS, Lublin, s. 227-237.

Prezydent z pensja i przywilejami a pierwsza dama ,, stuży” za darmo, 26.05.2015, https://tvn24bis.pl/z-kraju,74/prezydent-z-pensja-i-przywilejami-a-pierwsza-dama,545723.html (dostęp: 27.09.2018).

Prystacka, D. 2006. Zawód-żona polityka. Rola kobiet w kreowaniu wizerunku politycznego, „Środkowoeuropejskie Studia Polityczne", nr 1, s. 37-46. DOI: https://doi.org/10.14746/ssp.2006.1.03.

Secler, B. 2009. Miejsce i rola Pierwszej Damy w polskim życiu spoleczno-politycznym, [w:] Kobiety we współczesnej Europie. Rola i miejsce kobiet na rynku pracy, w polityce i społeczeństwie, M. Musiał-Karg (red.), Wydawnictwo Adam Marszałek, Toruń, s. 155-172.

Solska J. 2016. Żony władzy, 26.07, https://www.polityka.pl/tygodnikpolityka/spoleczenstwo/1669882,3,pierwsze-damy-nie-maja-latwo-zyja-w-klatce.read (dostęp: 15.09.2018).

Szewczyk, Ł. 2015. Humor w sieci. Liderem Demotywatory.pl, największe wzrosty notuja Bezuzyteczna.pl i Repostuj.pl, 01.02, http://media2.pl/internet/117679-Humor-w-sieci.-Liderem-Demotywatory.pl-najwieksze-wzrosty-notuja-Bezuzyteczna.pl-i-Repostuj.pl.html (dostęp: 5.09.2015).

Wawrowski, Ł. 2009. Zintegrowany model wyjaśniania - w poszukiwaniu przyczyn niedoreprezentowania kobiet $w$ strukturach politycznych, [w:] Pteć w życiu politycznym, M. Jeziński, M. Wincławska, B. Brodzińska (red.), Wydawnictwo Naukowe Uniwersytetu Mikołaja Kopernika, Toruń, s. 145-158. 
Wiśniewska, P.M. 2014. Wizerunek kobiety w mediach. Analiza porównawcza tematyki poświęconej kobietom w prasie polskiej i niemieckiej u schytku pierwszej dekady XXI wieku, Wydawnictwo Naukowe Silva Rerum, Poznań.

Wojtas, T. 2015. Serwisy z humorem: $w$ dót Demotywatory, Kwejk i Besty-zyskała Bezuzyteczna (TOP 15), 26.01., http://www.wirtualnemedia.pl/artykul/serwisy-z-humorem-w-dol-demotywatory-kwejk-i-besty -zyskala-bezuzyteczna-top-15/page:2 (dostęp: 6.09.2015).

\section{THE FIRST LADY IN ONLINE MEMES ON SELECTED EXAMPLES}

Examining the discourse appearing in memes is important because it shows which topics are particularly absorbing public opinion. The basis for the considerations will be the results of the quantitative and qualitative analysis, which was carried out on the example of over 200 memes published on the Demotywatory.pl portal. Empirical research was based on the analysis of the frequency of the frequency-thematic type, and the SPSS program was used as a research tool. The point of theoretical reference was the model of integrated explanation of the causes of gender inequality in politics, which allows us to look at the research material from a perspective that takes into account elements of equality policy. The analyses conducted for the purposes of this article made it possible to verify the research hypothesis: Cultural reasons for gender inequalities in politics, especially stereotyping, are the main element visible in the image of the First Lady of Poland, created in the memes analyzed.

The article is divided into three parts. The introduction included the basic theoretical findings regarding the political activity of women and Internet memes. In addition, the methodology of the conducted research is presented in detail (research method, hypothesis and research questions). The main part is the presentation of the results of quantitative and qualitative research on selected internet memes. The aim of the research was to check what image of the first lady was created in the memes studied. Differences and similarities in the imaging of the first lady of Poland and other countries of the world have been shown. Seeking answers to a number of questions: what do the memes' creators pay most attention to when it comes to the image of the president's wife, or in the memes we can see the presence of gender stereotypes, in which periods the interest in the first lady is the greatest and has something changed over the years? The third fragment is the ending, in which the research results are summarized and the research hypothesis confirmed. The image of the first lady seen in the analyzed memes is an example of the stereotypical depiction of a woman present in the sphere of politics, which is part of the cultural causes of under-representation of women in politics, which were indicated in an integrated model of explaining the causes of gender inequality in politics.

Keywords: first lady, memes, gender inequality

\section{BIOGRAM}

Katarzyna Brzoza, doktor nauk społecznych w zakresie nauk o polityce, adiunkt w Zakładzie Komunikacji Społecznej Instytutu Nauk Politycznych i Dziennikarstwa Uniwersytetu Śląskiego w Katowicach. Główne zainteresowania badawcze: kobieta w mass mediach, komunikowanie lokalne, komunikowanie masowe i polityczne. Kontakt e-mail: katarzyna.brzoza@us.edu.pl. 